\title{
EVALUATION OF S170 TALL FESCUE AT INVERMAY AGRICULTURAL RESEARCH CENTRE
}

\author{
R. B. Alien and N. A. Cullen \\ Invermay Agricultural Research Centre, Mosgiel
1. Use of Tall Fescue in Pasture Mixtures (R.B.A.; N.A.C.)

S170 tall fescue was compared with Ruanui ryegrass and Apanui cocksfoot in two mowing trials at lnvermay from 1968 to 1971. One site was located on a fertile Wingatui recent alluvial silt loam soil, and the other on a Warepa series yellow-grey hill soil of medium-low fertility.

The seeding rates were ryegrass 16.8, cocksfoot 9.0, and tall fescue, $22.5 \mathrm{~kg} / \mathrm{ha}$. All treatments were sown with basal Huia whdte clover and Turoa red clover, each at $3.4 \mathrm{~kg} / \mathrm{ha}$. A basal dressing of $630 \mathrm{~kg} /$ ha molybdenum-superphosphate, $250 \mathrm{~kg} / \mathrm{ha}$ $\mathrm{KCl}$, and $2500 \mathrm{~kg} / \mathrm{ha}$ lime was applied at each site, followed by annual maintenance applications.

Two cutting regimes we're imposed: frequent (2- to 3-week intervals), and infrequent (4- to 6-week intervals) .

Establishment of seedlings was satisfactory, but an assessment 6 months after sowing showed that, although ryegrass had formed a dense swasd on both sites, cocksfoot and tall fescue cover was comparatively sparse.

The major features of the results were:

(1) Over the 3-year period there was little difference in total production between, the tall 'fescue and ryegrass treatments (Table 1). Under frequent cutting the yield's were almost identical, while under infrequent cutting ryegrass outyielded tall fescue by less than $5 \%$.

Total production from the cocksfoot treatment was simillar to that of the tall fescue under lower fertility conditions, but tall fescue was 12 to $14 \%$ more productive than cocksfoot under higher fertility.

At both sites the ryegrass treatment was significantly more productive than the tall fescue and cocksfoot in the first year under both cutting regimes (Table 1). In the second year there were no significant differences in production on the hill site, but the tall fescue treatment was significantly 
TABLE 1: TOTAL HERBAGE DRY MATTER PRODUCTION (kg/ha)

\begin{tabular}{|c|c|c|c|c|c|c|c|c|}
\hline \multirow[b]{2}{*}{ Site and Treatment } & \multicolumn{2}{|c|}{$1968-9$} & \multicolumn{2}{|c|}{$1969-70$} & \multicolumn{2}{|c|}{ 1970-1 } & \multicolumn{2}{|c|}{ Total } \\
\hline & Freq. & Infreq. & Freq. & Infreq. & Freq. & Infreq. & Freq. & Infreq. \\
\hline Hill: & & & & & & & & \\
\hline $\begin{array}{l}\text { Tall focrue } \\
\text { Ryegrass }\end{array}$ & $53690 a^{b^{*}}$ & $\begin{array}{l}6138 \mathrm{~h} \\
7680 \mathrm{a}\end{array}$ & 18978 a & $\begin{array}{l}11830 \mathrm{a} \\
11320 \mathrm{a}\end{array}$ & $\begin{array}{l}8 \\
78600_{a}^{a}\end{array}$ & $11770 a$ & 23790 & $\begin{array}{l}28 \\
30\end{array} 660$ \\
\hline Cocksfoot & $4970 b$ & $6100 b$ & $10400 \mathrm{a}$ & $11560 a$ & $8120 \mathrm{a}$ & $10540 \mathrm{a}$ & 23490 & 28200 \\
\hline Plain: Tall fescue & $9980 \mathrm{~b}$ & $14600 \mathrm{~b}$ & $10900 \mathrm{a}$ & $13050 \mathrm{a}$ & $11880 a$ & 14240 a & 32760 & 41880 \\
\hline Ryegrass & $11870 \mathrm{c}$ & $12240 a_{c}$ & $87548 b_{b}$ & $11460 \mathrm{~b}$ & $113100 \mathrm{a}$ & $142100 \mathrm{a}$ & 33459 & 36690 \\
\hline
\end{tabular}

*Duncan's Multiple Range Test: values within each column at each site without a common letter differ significantly $(P<0.05)$.

TABLE 2: SOWN SPECIES \% OF TOTAL DRY MATTER

\begin{tabular}{|c|c|c|c|c|c|c|c|c|c|c|c|c|}
\hline \multirow[b]{2}{*}{ Site and Treatment } & \multicolumn{4}{|c|}{$1968-9$} & \multicolumn{4}{|c|}{$1969-70$} & \multicolumn{4}{|c|}{$1970-71$} \\
\hline & $\begin{array}{l}\text { Freq. } \\
\text { Gr. }\end{array}$ & $\mathrm{Cl}$. & $\begin{array}{l}\text { In } \\
\text { Gr. }\end{array}$ & q. & $\begin{array}{l}\text { Freq. } \\
\text { Gr. }\end{array}$ & $\mathrm{Cl}$. & $\begin{array}{l}\ln t \\
\text { Gr. }\end{array}$ & $\mathrm{Cl}$. & $\begin{array}{l}\text { Freq. } \\
\text { Gr. }\end{array}$ & $\mathrm{Cl}$. & $\begin{array}{l}\text { Infrec } \\
\text { Gr. }\end{array}$ & $\mathrm{Cl}$. \\
\hline Hill: Tall fescue & 14 & 48 & 16 & 42 & 12 & 68 & 19 & 69 & 27 & 52 & 26 & 59 \\
\hline \multirow{2}{*}{$\begin{array}{l}\text { Ryegrass } \\
\text { Cocksfoot }\end{array}$} & 53 & 34 & 54 & 29 & 15 & 73 & 21 & 10 & 27 & 55 & 31 & 59 \\
\hline & 17 & 43 & 25 & 38 & 22 & 64 & 37 & 56 & 34 & 51 & 51 & 45 \\
\hline \multicolumn{13}{|l|}{ Plain: } \\
\hline Tall fescue & 67 & 28 & 84 & 15 & 63 & 26 & 60 & 34 & 48 & 34 & 58 & 31 \\
\hline Ryegrass & 91 & 7 & 93 & 7 & 46 & 50 & 47 & 51 & 50 & 40 & 62 & 36 \\
\hline Cocksfoot & 74 & 20 & 85 & 12 & 61 & 29 & 60 & 35 & 62 & 26 & 71 & 22 \\
\hline
\end{tabular}


more productive than ryegrass and cocksfoot on the plains site under both cutting regimes. There were no significant differences in production in the third year.

(2) In the first year the percentage of sown grass was considerably higher and that of clover lower in the ryegrass treatment than in the tall fescue or cocksfoot treatments (Table 2). In the latter treatments there was a relatively high percentage of weed grasses and other species in the first year on the hill site. In the second year the sown grass percentage of the ryegrass treatments on both sites dropped considerably, while the clover increased.

(3) An effect of soil fertility was evident in the proportions of sown grass and clover at each site. On the lower fertility site the percentage of sown grass was lower than that of the same treatment on the higher fertility, site, and the percentage of clover correspondingly higher.

Total dry matter production from the higher fertility site averaged $37 \%$ greater than that from the lower fertility site.

(4) Frequency of cutting had little effect on the proportions of sown grass and clover in each season, but infrequent cutting resulted in an overall increase of approximately $25 \%$ in total dry matter production.

\section{CONCLUSIONS}

Total dry matter production over three years at the higher fertility site was similar in the tall fescue and ryegrass swards, exceeding that of the cocksfoot sward. At the lower fertility site, total dry matter production was similar in the three swards.

\section{Lucerne/ Grass Mixures}

(N.A.C.)

Eight lucerne/grass mixtures and lucerne alone were compared at Invermay from 1957 to 1960 . The companion grasses and their seeding rates were cocksfoot 1.8 , timothy 0.9, S215 meadow fescue 1.8 , N.Z. perennial ryegrass 2.7 , short-rotation ryegrass 0.9 , phalaris $4.5, \mathrm{~S} 170$ tall fescue. 3.6 , and prairie grass $2.7 \mathrm{~kg} / \mathrm{ha}$.

All plots were sown with $0.9 \mathrm{~kg} / \mathrm{ha}$ each of Moatgomery red clover and New Zealand white clover, and $7.1 \mathrm{~kg} / \mathrm{ha}$ Wairau lucerne. The control lucerne plot was sown at $12.5 \mathrm{~kg} / \mathrm{ha}$. Lime at $2000 \mathrm{~kg} / \mathrm{ha}$ had been applied in 1956, and a basal dressing of 
$200 \mathrm{~kg} / \mathrm{ha}$ lime-reverted 'superphosphate was applied, followed by annual maintenance applications. The grass/clover mixture and lucerne were drilled in alternate rows spaced at $180 \mathrm{~mm}$.

The treatments were cut four times. per seasoa. Results': are shown in Table 3.

TABLE 3: TOTAL HERBAGE DRY MATTER PRODUCTION, AND SOWN GRASS CONTRIBUTION, OF GRASS/LUCERNE MIXTURES AND LUCERNE ALONE (kg/ha)

\begin{tabular}{|c|c|c|c|c|c|c|}
\hline & & & $1957-8$ & 1958-9 & $1959-60$ & Total \\
\hline \multicolumn{7}{|l|}{ Tall fescue: } \\
\hline Total & & ." & 11280 & 6930 & 12630 & 30840 \\
\hline Grass & $\ldots$ & $\ldots$ & 6790 & 3180 & 3920 & 13890 \\
\hline \multicolumn{7}{|c|}{ Perennial ryegrass: } \\
\hline Total & & 111 & 10460 & 6470 & 11690 & 28620 \\
\hline Grass & $\ldots$ & $\therefore$ & 8390 & 2780 & 2520 & 13690 \\
\hline \multicolumn{7}{|l|}{ Cocksfoot: } \\
\hline Total & & ... & 8550 & 1180 & 11840 & 27570 \\
\hline Grass & $\ldots$ & $\ldots$ & 4720 & 2740 & 4900 & 12360 \\
\hline \multicolumn{7}{|l|}{ Prairie Grass: } \\
\hline Total & $\ldots$ & .'. & 10740 & 6100 & 10490 & 27330 \\
\hline Grass & $\ldots$ & $\ldots$ & 7270 & 1200 & 1450 & 992 \\
\hline \multicolumn{7}{|l|}{ S.R. Rye: } \\
\hline Total & $\ldots$ & $\ldots$ & 11820 & 5100 & 11710 & 28630 \\
\hline Grass & & $\ldots$ & 11380 & 2470 & 3960 & 17810 \\
\hline \multicolumn{7}{|l|}{ Timothy: } \\
\hline Total & & m." & 7580 & 5720 & 11900 & 25200 \\
\hline Grass & $\ldots$ & $\ldots$ & 4430 & 1250 & 1340 & 7020 \\
\hline \multicolumn{7}{|l|}{ Phalaris: } \\
\hline Total & $\ldots$ & $\ldots$ & 9550 & 5920 & 11700 & 27170 \\
\hline Grass & & $\ldots$ & 4660 & 740 & 1490 & 689 \\
\hline \multicolumn{7}{|c|}{ Meadow Fescue: } \\
\hline Total & $\ldots$ & $\ldots .$. & 7990 & 7650 & 12620 & 28260 \\
\hline Grass & $\ldots$ & $\ldots$ & 4520 & 1030 & 420 & 5970 \\
\hline \multicolumn{7}{|l|}{ Lucerne: } \\
\hline Total & $\ldots$ & ... & 5820 & 6520 & 11590 & 23930 \\
\hline Lucerne & $\ldots$. & $\ldots$ & 3100 & 5580 & 10550 & $1923 c$ \\
\hline
\end{tabular}

Over the three-year period. $\$ 170$ tall fescue provided one of the best mixtures. Although the two ryegrass treatments were also highly productive, this was largely because of the high ryegrass content in the first year, and resulted in some suppression of the lucerne.

"Results from this experiment were reported in more detail by N. A. Cullen, N.Z. Jl agric. Res., 8: 613-34 (1965). 
Little meadow fescue survived the three years and timothy, phalaris, cocksfoot and prairie' grass failed to show any outstanding attributes except that prairie grass was very productive during winter.

Although cocksfoot is widely sown as a companion grass with lucerne, in this trial S170 tall fescue proved superior. Tall fescue was slow to establish, but winter and summer production from the well-established tall fescue mixture was good and weed infestation was low. Tall fescue is a non-aggressive species and consequently provided a good balance of sown grass and lucerne.

\section{CONCLUSION}

In this experiment tall fescue proved a satisfaotary companion grass with lucerne. The mixture proved superior to lucerne sown alone as it was moire productive in the first year, gave better weed control and provided extra winter production. 